\title{
Chelation activity and protective effect of Caulerpa lentillifera aqueous extract against lead acetate-induced toxicity in Sprague Dawley rats
}

\author{
Dzulsuhaimi Daud ${ }^{1,2^{*}}$, Ahmad Nazrin Zainal ${ }^{2}$, Muhammad Naqib Nordin ${ }^{2}$, Alene Tawang ${ }^{3}$, Asmida Ismail ${ }^{2}$ \\ ${ }^{1}$ Faculty of Applied Sciences, Universiti Teknologi MARA, Perak Branch, Tapah Campus, Tapah Road, 35400 Perak, Malaysia. \\ ${ }^{2}$ Faculty of Applied Sciences, Universiti Teknologi MARA (UiTM), 40450 Shah Alam, Selangor, Malaysia. \\ ${ }^{3}$ Faculty of Science and Mathematics, Universiti Pendidikan Sultan Idris, 35900 Tanjong Malim, Perak, Malaysia.
}

\begin{tabular}{l}
\hline ARTICLE INFO \\
\hline Received on: $01 / 08 / 2019$ \\
Accepted on: $25 / 06 / 2020$ \\
Available online: $05 / 08 / 2020$
\end{tabular}

Key words:

Caulerpa lentillifera, lead, chelation, liver functions, heavy metals.

\begin{abstract}
Lead is a multisystemic toxicant when it accumulates and is hazardous to health. This study was conducted to determine the effect of Caulerpa lentillifera aqueous extract on lead accumulation in the internal organs and liver functions of lead-intoxicated rats. Sprague Dawley rats $(n=24)$ were divided into four groups $(n=6)$. Group I was healthy rats treated with saline $(2 \mathrm{ml} / \mathrm{kg}$ bwt) daily for 28 days. Group II was healthy rats treated with $C$. lentillifera aqueous extract ( $500 \mathrm{mg} / \mathrm{kg}$ bwt) daily for 28 days. Group III was intoxicated with lead acetate $(20 \mathrm{mg} / \mathrm{kg}$ bwt) daily for 4 days and then treated with saline ( $2 \mathrm{ml} / \mathrm{kg}$ bwt) for another 24 days. Group IV was intoxicated with lead acetate $(20 \mathrm{mg} / \mathrm{kg}$ bwt) daily for 4 days and then treated with C. lentillifera aqueous extract (500 mg/kg bwt) for another 24 days. Lead accumulation in the internal organs was measured by the atomic absorption spectrophotometer and the liver function markers were determined using assay kits. Lead intoxication significantly $(p<0.05)$ increased lead accumulation in the rats' internal organs and affected their liver functions. C. lentillifera aqueous extract supplementation to leadintoxicated rats significantly $(p<0.05)$ decreased lead accumulation in the rats' internal organs and protected their liver functions. This study concludes that $C$. lentillifera aqueous extract possesses the capability of a chelating agent and attenuates the effect of lead on lead-intoxicated rats.
\end{abstract}

\section{INTRODUCTION}

Lead is one of the most toxic heavy metals and it is widely used in the manufacturing industry (Flora et al., 2012). Normally, human beings are exposed to lead through the respiratory and gastrointestinal systems. The exposure to lead originates from numerous sources, including contaminated water, food, air, and soil. When exposed to lead, it enters the body system and accumulates in various internal organs, including the liver and kidneys (Adikwu et al., 2013). Nowadays, lead poisoning is treated by using antidotes commonly known as chelators. However, chelators have many adverse effects and are expensive and are

\footnotetext{
${ }^{*}$ Corresponding Author

Dzulsuhaimi Daud, Faculty of Applied Sciences, Universiti Teknologi MARA, Perak Branch, Tapah Campus, Tapah Road, 35400 Perak, Malaysia.E-mail: dzuls990@uitm.edu.my
}

sometimes not readily available (Offor et al., 2017). Therefore, scientists are trying to produce plant-based antidotes that are not only more effective but also have fewer side effects (Thenmozhi et al., 2013). The administration of antioxidants has been reported to protect against heavy metal-induced tissue damage by inactivating the generated reactive oxygen species and maintaining the heavy metal in a redox state (Garcia and Gonzalez, 2008).

Caulerpa lentillifera is an alga rich in natural antioxidants and has a high content of nutrients (Matanjun et al., 2009). This type of microalga is a popular edible species due to its soft and succulent texture, which is eaten fresh or salted. As a medicine, it has antibacterial, antifungal, anticancer, antidiabetic, antihypertensive, and lipid-lowering properties (Sharma and Rhyu, 2014). As far as our literature survey ascertains, no attempt has been made to study the role of $C$. lentillifera against lead accumulation in internal tissues. Thus, this study was conducted to determine the chelation capacity of $C$. lentillifera in male rats. To test the hypothesis, we 
measured the amount of lead accumulation in the internal organs of lead-intoxicated rats, with and without the treatment of $C$. lentillifera aqueous extract. We also observed the physical signs of illness and liver function markers of the respective rats.

\section{MATERIALS AND METHODS}

\section{Plant material and extract preparation}

Caulerpa lentillifera was collected from Kota Kinabalu, Sabah, Malaysia, and authenticated by Ahmad Ismail, botanist at the Universiti Kebangsaan Malaysia. The voucher specimen was deposited at the Biology Laboratory, Universiti Teknologi MARA, Shah Alam, Selangor, Malaysia. The washed C. lentillifera were thermally dried in a hot air oven (Sanyo MOV-212F-PE, Sanyo Ltd., Fukuoka, Japan) at $60^{\circ} \mathrm{C}$ until constant weight (Nguyen et al., 2011). The aqueous extract was prepared as described by Daud et al. (2016). About $250 \mathrm{~g}$ of dried $C$. lentillifera was soaked in 4 1 of boiled water until the water became half. Then, the mixture was filtered and centrifuged (3,000 rpm, 15 minutes) to harvest the clear supernatant. The supernatant was then concentrated and dried under vacuum (BUCHI Rotavapor R120, BUCHI Labortechnik AG, Flawil, Switzerland). The aqueous extract was stored at $4{ }^{\circ} \mathrm{C}$ and later freshly dissolved in saline prior to the experiment.

\section{Animals and experimental protocols}

Twenty-four male 4-week-old Sprague Dawley rats, with initial body weight between 150 and $180 \mathrm{~g}$, were used (Chenur Supplier, Malaysia). The animals were kept in polyethylene cages with access to rodent pellets and water ad libitum. The procedures for animal handling were approved by the Faculty of Applied Sciences Research Ethics Committee, Universiti Teknologi MARA. After 2 weeks of acclimatization to the laboratory conditions, the rats were randomly assigned to four groups $(n=6)$. Group I $(n=6)$ was orally gavaged with saline ( $2 \mathrm{ml} / \mathrm{kg}$ bwt) for 28 days, Group II ( $n=$ 6 ) was orally gavaged with $C$. lentillifera aqueous extract $(500 \mathrm{mg} /$ $\mathrm{kg}$ bwt) for 28 days, and Group III $(n=6)$ was orally gavaged with lead acetate $(20 \mathrm{mg} / \mathrm{kg}$ bwt $)$ for 4 days, followed by saline $(2 \mathrm{ml} / \mathrm{kg}$ bwt) for another 24 days. Meanwhile, Group IV $(n=6)$ was orally gavaged with lead acetate $(20 \mathrm{mg} / \mathrm{kg}$ bwt) for 4 days, followed by C. lentillifera aqueous extract ( $500 \mathrm{mg} / \mathrm{kg}$ bwt) for another 24 days. Each rat was examined daily for behavioral and clinical symptoms (Daud et al., 2015). On day 29, all the rats were sacrificed by overdose of diethyl ether (Merck KGaA, Darmstadt, Germany). Blood and organs (liver, kidney, and testis) were collected for the estimation of lead accumulation. In addition, blood serum was harvested for estimation of liver function markers.

\section{Estimation of the amount of lead accumulation}

The measurement of lead concentration was conducted as described by Daud et al. (2015). The blood sample was digested with 65\% nitric acid (BDH Analytical Chemicals, United Kingdom) with a ratio of $1: 2$. Then, the sample was incubated for 15 minutes at room temperature and centrifuged. The supernatant was collected and made up to $25 \mathrm{ml}$ by adding deionized water, followed by the estimation of lead by the spectrophotometer technique (Shimadzu Model AA-670, Kyoto, Japan) at a wavelength of $217 \mathrm{~nm}$. Meanwhile, for the other tissues (liver, kidney, and testis), each was cleaned with physiological saline and homogenized with a pestle and mortar Afterward, $5 \mathrm{~g}$ of the tissue was digested with $10 \mathrm{ml}$ of $65 \%$ nitric acid (BDH Analytical Chemicals, United Kingdom). Then, the mixture was heated $\left(70^{\circ} \mathrm{C}\right)$ until it became colorless. The mixture was allowed to cool at room temperature and made up to $25 \mathrm{ml}$ by adding deionized water. Finally, the mixture was filtered by using Whatman Filter Paper No. 41. The lead content was measured by the spectrophotometer (Shimadzu Model AA-670, Kyoto, Japan) at a wavelength of $217 \mathrm{~nm}$.

\section{Estimation of liver function markers}

Alanine aminotransferase (ALT), aspartate aminotransferase (AST), and alkaline phosphatase (ALP) concentrations in the blood serum were determined by using assay kits, according to the manufacturer's manual (Sigma-Aldrich, Germany).

\section{Statistical analysis}

The data were presented as mean \pm SEM. All gathered data were analyzed using one-way analysis of variance (statistically significant at $p<0.05$ ).

\section{RESULTS AND DISCUSSION}

\section{Physical signs of illness}

Lead-intoxicated rats demonstrated multiple signs of illness (Table 1). Damstra (1977) documented that lead intoxication results in well-characterized syndromes, such as fatigue/lethargy and loss of appetite and body weight. Body weight was significantly lower $(p<0.05)$ in Group III (lead acetate-treated group) compared to Group I (control rats). Similarly, Ibrahim et al. (2012) reported that the body weight decreases in lead-intoxicated albino male rats. Lead poisoning causes the absorption of nutrients to be impaired, resulting in weight loss (Alwaleedi, 2016). According to Sharma et al. (2011), lead selectively binds to proteins in tissues, disrupts their functions, and results in weight loss. This could be due to imbalanced protein and other biomolecules' metabolism in lead-intoxicated rats (Seddik et al., 2010). On the contrary, Sun et al. (2017) documented that lead promotes an increase in body weight in adult Wistar rats through the induction of insulin

Table 1. Effect of $C$. lentillifera aqueous extract on the behavioral and clinical symptoms (physical signs of illness) in lead-intoxicated rats.

\begin{tabular}{lcccc}
\hline Physical sign & I & II & III & IV \\
\hline Piloerection & - & - & + & - \\
Lethargy & - & - & + & - \\
Hair loss & - & - & + & - \\
Dark urine & - & - & + & - \\
Diarrhea & - & - & - & - \\
Paleness of skin & - & - & + & - \\
Mortality & - & - & - & - \\
Body weight $(\mathrm{g})$ & $287.3 \pm 7.7^{\mathrm{a}}$ & $293.8 \pm 5.1^{\mathrm{a}}$ & $219.4 \pm 8.3^{\mathrm{b}}$ & $254.9 \pm 4.9^{\mathrm{c}}$ \\
\hline
\end{tabular}

Group I: control rats treated with $2 \mathrm{ml} / \mathrm{kg}$ bwt distilled water; Group II: $500 \mathrm{mg} / \mathrm{kg}$ bwt $C$. lentillifera aqueous extract; Group III: $20 \mathrm{mg} / \mathrm{kg}$ bwt lead acetate; and Group IV: $500 \mathrm{mg}$ / $\mathrm{kg}$ bwt $C$. lentillifera aqueous extract $+20 \mathrm{mg} / \mathrm{kg}$ bwt lead acetate

Note: "+" indicates the presence of illness and "-" indicates the absence of illness. Values with different superscripts within the same row show significant differences at $p<0.05$. 
Table 2. Effect of $C$. lentillifera aqueous extract on lead accumulation in lead-intoxicated rats.

\begin{tabular}{lcccc}
\hline Organs & I & II & III & IV \\
\hline Blood $(\mu \mathrm{g} / \mathrm{l})$ & $0.0038 \pm 0.000 \mathrm{E}^{\mathrm{a}}$ & $0.0036 \pm 0.000 \mathrm{E}^{\mathrm{a}}$ & $0.3165 \pm 0.08^{\mathrm{b}}$ & $0.2075 \pm 0.04^{\mathrm{c}}$ \\
Liver $(\mu \mathrm{g} / \mathrm{g})$ & $0.0036 \pm 0.000 \mathrm{E}^{\mathrm{a}}$ & $0.0042 \pm 0.000 \mathrm{E}^{\mathrm{a}}$ & $0.3021 \pm 0.07^{\mathrm{b}}$ & $0.2341 \pm 0.09^{\mathrm{c}}$ \\
Kidney $(\mu \mathrm{g} / \mathrm{g})$ & $0.0032 \pm 0.000 \mathrm{E}^{\mathrm{a}}$ & $0.0038 \pm 0.000 \mathrm{E}^{\mathrm{a}}$ & $0.3042 \pm 0.05^{\mathrm{b}}$ & $0.2563 \pm 0.07^{\mathrm{c}}$ \\
Testis $(\mu \mathrm{g} / \mathrm{g})$ & $0.0024 \pm 0.000 \mathrm{E}^{\mathrm{a}}$ & $0.0028 \pm 0.000 \mathrm{E}^{\mathrm{a}}$ & $0.2781 \pm 0.03^{\mathrm{b}}$ & $0.1981 \pm 0.06^{\mathrm{c}}$ \\
\hline
\end{tabular}

Group I: control rats treated with $2 \mathrm{ml} / \mathrm{kg}$ bwt distilled water; Group II: $500 \mathrm{mg} / \mathrm{kg}$ bwt C. lentillifera aqueous extract; Group III: $20 \mathrm{mg} / \mathrm{kg}$ bwt lead acetate; and Group IV: $500 \mathrm{mg} / \mathrm{kg}$ bwt C. lentillifera aqueous extract $+20 \mathrm{mg} / \mathrm{kg}$ bwt lead acetate. Values are presented as means $\pm \operatorname{SE}(n=6)$.

Values with different superscripts within the same row show significant differences at $p<0.05$.

Table 3. Effect of $C$. lentillifera aqueous extract on liver function markers in lead-intoxicated rats.

\begin{tabular}{lcccc}
\hline Markers & I & II & III & IV \\
\hline ALT $(\mathrm{U} / \mathrm{ml})$ & $44.35 \pm 3.21^{\mathrm{a}}$ & $41.69 \pm 2.14^{\mathrm{a}}$ & $127.47 \pm 1.19^{\mathrm{b}}$ & $67.51 \pm 3.74^{\mathrm{c}}$ \\
AST $(\mathrm{U} / \mathrm{ml})$ & $140.31 \pm 4.61^{\mathrm{a}}$ & $150.73 \pm 2.57^{\mathrm{a}}$ & $204.16 \pm 4.88^{\mathrm{b}}$ & $173.11 \pm 3.49^{\mathrm{c}}$ \\
ALP $(\mathrm{U} / \mathrm{ml})$ & $38.93 \pm 2.49^{\mathrm{a}}$ & $39.65 \pm 1.24^{\mathrm{a}}$ & $82.78 \pm 3.87^{\mathrm{b}}$ & $52.56 \pm 2.63^{\mathrm{c}}$ \\
\hline
\end{tabular}

Group I: control rats treated with $2 \mathrm{ml} / \mathrm{kg}$ bwt distilled water; Group II: $500 \mathrm{mg} / \mathrm{kg}$ bwt $C$. lentillifera aqueous extract; Group III: $20 \mathrm{mg} / \mathrm{kg}$ bwt lead acetate; and Group IV: $500 \mathrm{mg} / \mathrm{kg}$ bwt C. lentillifera aqueous extract $+20 \mathrm{mg} / \mathrm{kg}$ bwt lead acetate. Values are presented as means $\pm \operatorname{SE}(n=6)$.

$\mathrm{ALT}=$ alanine aminotransferase $\mathrm{AST}=$ aspartate aminotransferase $; \mathrm{ALP}=$ alkaline phosphatase

Values with different superscripts within the same row show significant differences at $p<0.05$.

resistance. Interestingly, body weight was significantly higher $(p<$ 0.05 ) in Group IV (lead-intoxicated rats treated with C. lentillifera aqueous extract) in comparison with Group III (lead acetatetreated group). This indicates the capability of $C$. lentillifera in reducing the effect of lead on the satiety set point and nutrient metabolism. Meanwhile, the $C$. lentillifera aqueous extract alone has no significant effect on body weight and other signs of illness as observed in Group II.

\section{Lead accumulation in blood and internal organs of rats}

Rats exposed to lead acetate (Group III) has a significantly higher $(p<0.05)$ accumulation of lead in the blood and internal organs in comparison with Group I (control rats). Findings from our study reveal that $C$. lentillifera aqueous extract significantly reduced $(p<0.05)$ lead accumulation in the blood and internal organs of rats exposed to lead acetate as observed in Group IV (Table 2). A previous study reported that $C$. lentillifera contains polyphenols (Sharma and Rhyu, 2014), which are known for their metal-chelating ability (Perron and Brumaghim, 2009). This might be one of the mechanisms by which $C$. lentillifera decreases lead accumulation in the blood and internal organs. In addition, the potential of $C$. lentillifera in reducing lead accumulation can be said to be due to the presence of sulfur and other compounds with amino acid in their structure. Badiei et al. (2006) stated that these biological elements have the ability to remove lead from the body system. However, further studies have to be carried out to determine the actual mechanism.

\section{Liver functions}

The values of liver function markers are presented in Table 3. Exposure to lead acetate resulted in a significant increase $(p<0.05)$ in serum ALT, AST, and ALP activities of Group III (lead acetate-treated group) compared to Group I (control group). These results have also been observed by other researchers (Heidarian and Rafieian-Kopaei, 2013). An elevation in the levels of ALT,
AST, and ALP indicates serious hepatic tissue damage (Kilikdar et al., 2011). The aqueous extract of $C$. lentillifera demonstrated a hepatoprotective effect since there was a significant decrease $(p$ $<0.05$ ) in these three enzymes in Group IV (lead-intoxicated rats treated with $C$. lentillifera aqueous extract) compared to Group III (lead acetate-treated group). Furthermore, rats in Group II (which received $C$. lentillifera aqueous extract) demonstrated no significant effect $(p>0.05)$ on the levels of ALT, AST, and ALP, clearly indicating that the extract by itself does not cause any adverse effect on the hepatic tissue.

\section{CONCLUSION}

It can be concluded that $C$. lentillifera aqueous extract is a promising candidate that can be used as a chelation agent and has a protective effect on lead-induced toxicity as that observed in the experimental rats.

\section{ACKNOWLEDGMENTS}

The authors would like to acknowledge the Institute of Research Management and Innovation (IRMI), Universiti Teknologi MARA, Malaysia, for the funding through Lestari Grant Scheme (600-IRMI/DANA KCM 5/3/LESTARI 119/2017) and the Faculty of Applied Sciences, Universiti Teknologi MARA, for the facilities provided.

\section{AUTHORS' CONTRIBUTIONS}

All authors were involved in the writing, revision, and final approval of this article.

\section{CONFLICT OF INTEREST}

The authors declare that there are no conflicts of interest regarding the publication of this article.

\section{FUNDING}

None. 


\section{REFERENCES}

Adikwu E, Deo O, Geoffrey OP, Enimeya DA. Lead organ and tissue toxicity: roles of mitigating agents (Part I). Br J Pharmacol Toxicol, 2013; 4:232-240.

Alwaleedi SA. Hematobiochemical changes induced by lead intoxication in male and female albino mice. Natl J Physiol Pharm Pharmacol, 2016; 6:46-51.

Badiei K, Mostaghni K, Nowrooziasl A, Naeini AT. Ameliorated effects of Allium sativum on subclinical lead toxicity in goats. Pak Vet J, 2006; 26:184-6.

Damstra T. Toxicological properties of lead. Environ Health Perspect, 1977; 19:297-307.

Daud D, Arsad NFM, Ismail A, Tawang A. Anti-pyretic action of Caulerpa lentillifera, Hibiscus rosa-sinensis and Piper sarmentosum aqueous extract in mice. Asian J Pharm Clin Res, 2016; 9:145-7.

Daud D, Nawi NM, Ismail A, Tawang A. The effect of Eucheuma cottonii on sperm quality and tissue lead levels in rats exposed to lead nitrate. Biotechnol Indian J, 2015; 11:138-43.

Flora G, Gupta D, Tiwari A. Toxicity of lead: a review with recent updates. Interdiscip Toxicol, 2012; 5:47-58.

Garcia MTA, Gonzalez ELM. Toxic effects of perinatal lead exposure on the brains of rats; Involvement of oxidative stress and the beneficial role of antioxidants. Food Chem Toxicol, 2008; 46:2089-95.

Heidarian E, Rafieian-Kopaei, M. Protective effect of artichoke (Cynara scolymus) leaf extract against lead toxicity in rat. Pharm Biol, 2013; 51:1104-9.

Ibrahim NM, Eweis EA, El-Beltagi HS, Abdel-Mobdy YE. Effect of lead acetate toxicity on experimental male albino rat. Asian Pac J Trop Biomed, 2012; 2(1):41-6.

Kilikdar D, Mukherjee D, Mitra E, Ghosh AK, Basu A, Chandra AM, Bandyoapdhyay D. Protective effect of aqueous garlic extract against lead-induced hepatic injury in rats. Indian J Exp Biol, 2011; 49:498-510.

Matanjun P, Mohamed S, Mustapha NM, Muhammad K. Nutrient content of tropical edible seaweeds, Caulerpa lentillifera and Sargassum polycystum. J Appl Phycol, 2009; 21:75-80.

Nguyen VT, Jinn-Pying U, Guo-Jane T. Proximate composition, total phenolic content and antioxidant activity of seagrape (Caulerpa lentillifera). J Food Sci, 2011; 76:950-8.
Offor SJ, Mbagwu HOC, Orisakwe OE. Lead induced hepatorenal damage in male albino rats and effects of activated charcoal. Front Pharmacol, 2017; 8:1-10.

Perron NR, Brumaghim JL. A review of the antioxidant mechanisms of polyphenol compounds related to iron binding. Cell Biochem Biophys, 2009; 53:75-100.

Seddik I, Bah TM, Aoues A, Brnderdour M, Silmani M. Dried leaf extract protects against lead-induced neurotoxicity in Wistar rats. Eur J Sci Res, 2010; 42(1):139-51.

Sharma BR, Rhyu DY. Anti-diabetic effects of Caulerpa lentillifera: stimulation of insulin secretion in pancreatic $\beta$-cells and enhancement of glucose uptake in adipocytes. Asian Pac J Trop Med, 2014; 4:575-80

Sharma V, Kansal L, Sharma A, Lodi S, Sharma SH Ameliorating effect of Coriandrum sativum extracts on haematological and immunological variables in an animal model of lead intoxication. J Pharm Allied Health Sci, 2011; 1:16-29.

Sun H, Wang N, Nie X, Zhao L, Li Q, Cang Z, Chen C, Lu M, Cheng J, Zhai H, Xia F, Ye L, Lu Y. Lead exposure induces weight gain in adult rats, accompanied by DNA hypermethylation. PloS One, 2017; 12:e0169958

Thenmozhi M, Dhanalakshmi M, Manjula-Devi K, Sushila K, Thenmozhi S. Evaluation of hepatoprotective activity of Leucas aspera hydroalcoholic leaf extract during exposure to lead acetate in male albino Wistar rats. Asian J Pharm Clin Res, 2013; 6:78-81.

How to cite this article:

Daud D, Zainal AN, Nordin MN, Tawang A, Ismail A. Chelation activity and protective effect of Caulerpa lentillifera aqueous extract against lead acetate-induced toxicity in Sprague Dawley rats. J Appl Pharm Sci, 2020; 10(08):145-148. 